As a result of the paper of Leon van den Broeke (Amsterdam), from the Reformed perspective, the group talked about how the principles neglect somewhat the law operative at the regional level of church governance; and from the presentation by John Chalmers (Edinburgh), speaking from the Presbyterian experience, discussion followed on the impact of civil law as a force for change in church law. The Baptist standpoint, elucidated by Paul Goodliff (Abingdon), challenged the group to think more critically about how practices and forms of soft law in churches are also an important source of norms of ecclesial conduct and how the principles may function as a bridge between doctrine (the traditional focus of ecumenical discourse) and action (the grassroots experience of ecumenism). Leo Koffeman (Amsterdam), speaking from the perspective of United Churches, proposed how the process of ecclesial unification actually lies at the heart of 'juridical ecumenism'. Angela Berlis (Berne), coming from the Old Catholic tradition and a much welcomed new member of the panel, led the group to discuss how church law is pedagogical, how it follows life and how the principles project turns the problem of church law (in the form of lex) as potentially divisive ecumenically into a possibility for unity (when it becomes ius). Another new member, Paul Rochester (London), gave a Pentecostal view, and thoughts on the extensive use of rules in its many traditions, leading the Panel to address the spiritual and functional aspects of church law.

All in all, the round table and fellowship shared underscored the innovativeness of and challenges for the imaginative use of church law as a potential unifying force in ecumenism at all its various levels. The panel next meets in Rome in November 2018.

\title{
The Eighteenth Colloquium of Anglican and Roman Catholic Canon Lawyers
}

\author{
Jesus College, Oxford, 27-28 May 2018
}

LUKE BECKETT OSB

Ampleforth Abbey

and

STEPHEN FARRELL

Rector of Zion Parish Church, Dublin 
Readers of this journal will be familiar with the old wheeze that Turl Street in Oxford is rather like the Church of England, in that it goes from the Broad to the High and passes Jesus somewhere in between. This charge could not be levelled at the latest Colloquium of Anglican and Roman Catholic Canon Lawyers, as we took the precaution of meeting in Jesus College. The idea of meeting in Jesus came from Professor Norman Doe, who was a visiting Fellow there for part of Trinity term. The location afforded opportunity to pause our work for evensong in the college chapel followed by a sumptuous dinner in hall, which saw the visiting Fellow forsake the delights of high table to dine with other members of the colloquium at low table. In the warm afternoon of the second day, spirits were raised by a visit to the historic Fellows' Library, and the sight of students in sub fusc and white carnations made all of us grateful that we were not about to face Schools.

Colloquium participants were warmly welcomed by Professor Doe and the Revd Dr Robert Ombres OP, both of whom set the tone for which the colloquium is known, being gatherings where fellowship is prized alongside academic encounter. This was greatly appreciated by participants, most of whom were attending the colloquium for only the first or second time. Five topics were considered, with an Anglican and a Catholic giving short papers under the same heading followed by group discussion. Siôn Hughes Carew (Church of England Legal Office) and the Revd Dr Luke Beckett OSB (Ampleforth Abbey) spoke on 'The sources of law'. The Revd Russell Dewhurst (Church of England) and Dr Ombres (Blackfriars, Oxford) considered 'The purposes of law'. The Revd Stephen Farrell (Church of Ireland) and the Revd Andrew Cole (Diocese of Nottingham) looked at 'The subjects of law'; and Charlotte Wright (Cardiff Law School and Church in Wales) and the Revd Dr Helen Costigane SHCJ (St Mary's University, London) gave papers on 'The structure of law'. Finally, the Ven Dr Jane Steen's (Church of England) paper was given in her absence by Prof Doe (Cardiff Law School and Church in Wales) alongside the paper by the Revd Dr James Campbell SJ (Campion Hall, Oxford), both on 'Enforcement and relaxation of law'. Also in attendance at the colloquium were Chancellor Mark Hill QC and the Revd Stephen Coleman (Church of England).

The focus of this year's colloquium was the topic of 'Canon law in action'. This raised the question of the relationship between lex and ius, a relationship often explored through questions about the status of the Principles of canon law in the Anglican Communion. These offered a case study in teasing out such issues as whether the ratio legis is part of the law or not and whether custom is truly law. Looking at the sources of law, it was clear that the Church of England is in many ways not typical of the whole Anglican Communion by reason of the close relationship that its law-making process has with Parliament: participants from the Church in Wales and the Church of Ireland 
were able to draw out the way that their experience lent itself more readily to a consensual contract model of legislation. This could also be contrasted with the essentially hierarchical model of legislation in the Roman Catholic Church though custom perhaps offered the possibility of a different approach here as well.

Reflection on the structures of law from the Catholic side offered thoughts about both the way in which the Code of Canon Law had an overall structure that had an influence on how individual canons were interpreted because it revealed the different ecclesiological presuppositions upon which the law was now constructed, and also about the different genres of law. This led us into analysis of the different types of law, which stimulated reflection on the way in which canon law embodied rights and duties, and how (from the Anglican side) fundamental canonical principles could be used to underpin and interpret the rules contained in individual canons.

One interesting aspect of contrast was seen in the Anglican notion that canon law only binds the clergy (or perhaps, more widely, office-holders in the Church), whereas Catholic canon law appears to bind all. One way in which this led us was to reflect on the notion that canon law can only bind in conscience; another was to reflect on the contemporary preference for non-legal means of resolution, which often either do not draw on the canonical tradition or explicitly distance themselves from it. The relationship of these so-called pastoral means to legal means was viewed both through the perspective of reactions to perceived legalism in the past and through the idea that canon law only binds in the forum of conscience. If 'canon law exists to assist a church in its mission and witness to Jesus Christ', the challenge of this newer approach must be met, and discussion looked at how freedom and law-making go together, and how canon law serves the salvation of souls even as it is juridical, canonical and theological.

Perhaps we could end by offering a definition of canon law which was proposed to the colloquium for consideration: 'canon law is the normative aggregate of divine and human laws as accepted or created by the Church'. Though presented from the Catholic perspective, teasing out the implications of this was at the heart of our colloquium. 